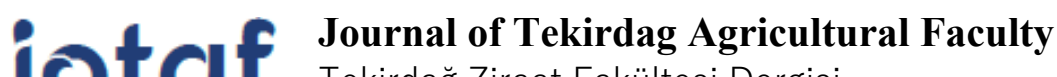 \\ Tekirdağ Ziraat Fakültesi Dergisi
}

\section{Identification of Virus Causes of Mosaic Diseases in Zucchini Plants in the Bali Island of Indonesia}

\author{
Ni Putu PANDAWANI ${ }^{1}$, I Ketut WIDNYANA ${ }^{2 *}$
}

\begin{abstract}
Mosaic disease has become epidemic in the zucchini (Cucurbita pepo L.) plantations on the island of Bali, but the cause of the disease is not yet known with certainty, although there are allegations of common causes including the Cucumber mosaic virus (CMV), Papaya ringspot virus (PRSV), Squash mosaic virus (SqMV), Watermelon mosaic virus (WMV), and Zucchini yellow mosaic virus (ZYMV). This study aims to ascertain the cause of the mosaic disease which was carried out by observation of the symptoms, proving Koch's postulates and using Indirect-ELISA serological tests. Indirect-ELISA method was carried out following the manufacturer's instructions DSMZ (Deutsche Sammlung von Mikroorganismen und Zellkulturen GmbH) Germany using several antisera namely, Zucchini yellow mosaic virus (ZYMV, DSMZ, Germany), Cucumber mosaic virus (CMV, Agdia Inc., USA) and Papaya ringspot virus (PRSV, Agdia Inc., USA). Results showed that the occurrence of mosaic diseases in zucchini plantations with very diverse symptoms as malformation and distortion of the leaves and the fruits, blistering, vein clearing, vein banding and shoestring symptoms with disease ranging from $87.17 \%$ to $92.72 \%$. Following of Koch's postulatesmechanical inoculations were carried out using mosaic diseased leaf extract obtained a success of transmission rate of $100 \%$. Where, healthy zucchini plants that were inoculated with mosaic symptomatic plants exhibit the same symptoms as mosaic symptoms found in the field. The main findings of this study are serological tests with Indirect-ELISA showed that $75 \%$ of zucchini plants were infected by ZYMV and as many as $8.33 \%$ were positive to CMV. There are no plants infected with PRSV. It can be concluded that the causes of zucchini mosaics on the island of Bali are ZYMV and CMV.
\end{abstract}

Keywords: Identification, Mosaic, Zucchini, ELISA, ZYMV

\footnotetext{
${ }^{1}$ Ni Putu Pandawani, Agriculture Departement of Mahasaraswati Denpasar University, Bali and Indonesia. E-mail: pandawaniputu@hotmail.com (iD) OrcID: 0000-0002-1347-3638.

2 Corresponding Author : I Ketut Widnyana, Agriculture Departement of Mahasaraswati Denpasar University, Bali and Indonesia. E-mail: widnyanaketut@gmail.com (D) OrcID: 0000-0002-4864-6578.

Atıf/Citation: Pandawani, N.P., Widnyana I.K., Identıfıcatıon of Vırus Causes of Mosaıc Dıseases in Zucchını Plants in the Balı Island of Indonesıa. Tekirdağ Ziraat Fakültesi Dergisi, 18 (3), 411-418

CBu çalışma Tekirdă̆ Namık Kemal Üniversitesi tarafından Creative Commons Lisansı (https://creativecommons.org/licenses/by-nc/4.0/) kapsamında yayınlanmıştır. Tekirdağ 2021
} 


\section{Introduction}

The zucchini planting centers in Bali are several villages in Baturiti District, Tabanan Regency and Sukasada District, Buleleng Regency. Since the last three years production has decreased by around 65\%. In fact, farmers do not get results because the plants do not bear fruit or the fruits are of poor quality. The decrease in the quantity and quality of zucchini is partly caused by pests and diseases. Symptoms of disease that occur in zucchini plantations are mosaic between dark and dark green on the leaves and around the leaf bone is greener than the leaves of the lamina (vein banding). Lamina leaves such as blisters on the green part (blistering), bleaching of leaf bones (vein clearing). Near young leaves, lamina growth is inhibited or even not formed at all so that the shape of the leaves is like shoelaces. Plants also show symptoms of malformation and distortion of leaves and fruit (Figure 1).

The occurrence of mosaic disease in zucchini plants is due to one or a combination of several types of viruses. The assumption is based on the fact, that there are several major mosaic-causing viruses that infect Cucurbitaceae, namely the Cucumber mosaic virus (CMV), Papaya ringpot virus (PRSV), Squash mosaic virus (SqMV), Watermelon mosaic virus (WMV), Zucchini yellow mosaic virus (ZYMV) (Coutts et al., 2011; Jossey and Babadoost, 2008) and Tobacco ringspot virus (TRSV) (Babadoost, 1999; Jossey and Babadoost, 2008). Lestari and Nurhayati (2014), reported the presence of several viruses on Cucurbitaceae plants found in West Java included CMV, SqMV and ZYMV.
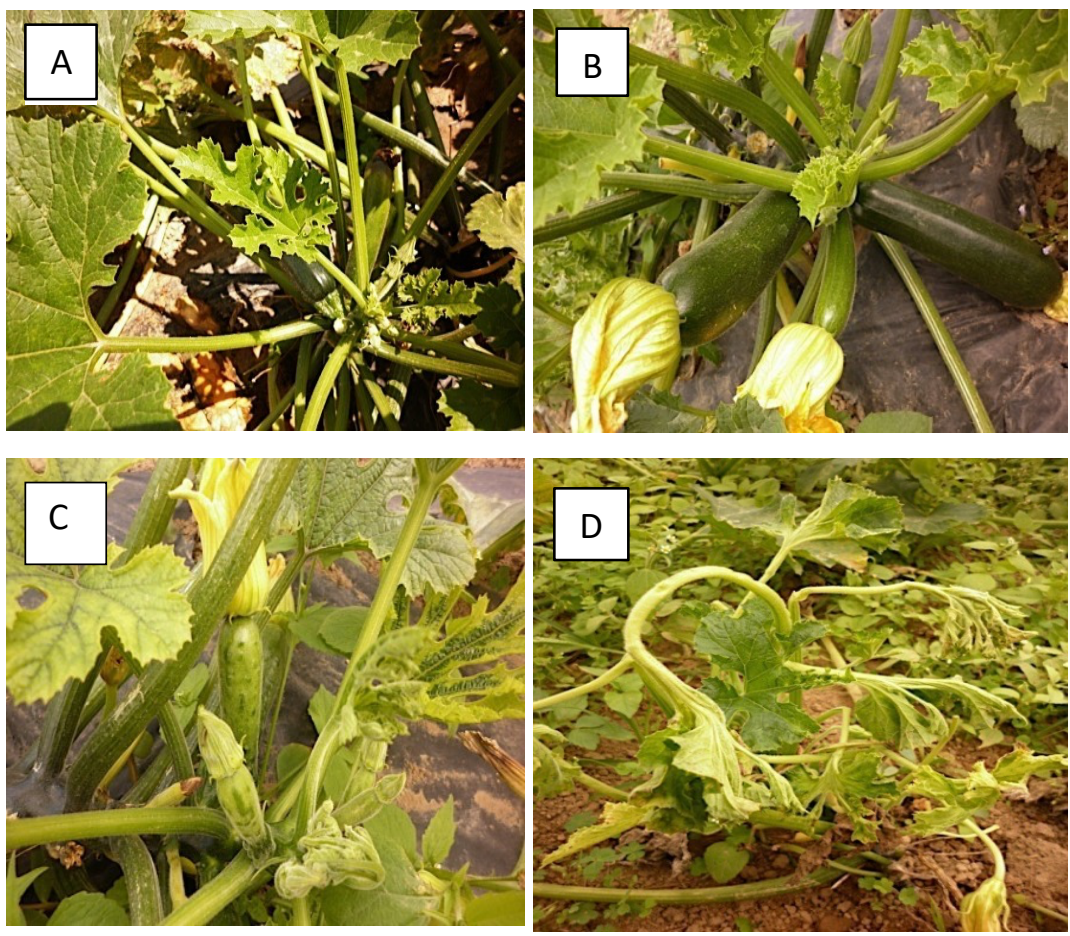

\section{Figure 1. The observation results on zucchini plants in the field, Healthy zucchini plants (A-B). Zucchini plants are diseased $(C-D)$}

Zucchini yellow mosaic virus (ZYMV) is a member of the Potyviridae family and is considered the most harmful virus that attacks cucurbit plants in the field (El-Aziz, 2020). This virus was first isolated in northern Italy (Lisa et al., 1981). Soon after, ZYMV was identified worldwide where cucurbit is cultivated, including Mediterranean countries, Japan, Germany, Central Europe, China, Chile, Australia, Mexico, Mauritius, Canada, and the United States (Desbiez and Lecoq, 1997; Prieto et al., 2001). In Australia, ZYMV was first detected in 1984, but symptomatic cucurbit plants were recorded in Western Australia (WA) in 1973 . Subsequently, it became widespread in cucurbit-growing areas in tropical Kununurra (WA), Ayr (Queensland, Qld) and Darwin (Northern Territory, NT), subtropical Carnarvon (WA), and temperate Swan Hill (Victoria, Vic) (Greber et al., 1987; Greber et al., 1988). 
This relatively new, but aggressive virus has spread rapidly throughout the world, exhibiting efficient plant-toplant transmission by several aphid species on a non-persistent basis (Lecoq and Pitrat, 1983) and long-distance distribution via infected seed (Davis and Mizuki, 1986; Schrijnwerkers et al., 1991; Fletcher et al., 2000). In Egypt, ZYMV was isolated from naturally infected pumpkin plants (Fath-Allah et al., 2011).

Zitter and Murphy (2009) reported that distinct strains of viruses could differ serologically. The second possibility is that the crops were infected by other distinct cucurbits viruses. Many authors reported that cucurbits could be infected by many viruses, commonly CMV, PRSV, ZYMV,WMV and others both in single or mix infection that induce a variety of symptoms including symptoms of CMV infection such as mosaic, vein clearing, vein banding and malformation (Zitter and Murphy 2009; Romay et al., 2014; Barbosa et al., 2016; Sydanmetsa and Mbanzibwa, 2016).

This study aims to identify the virus that causes mosaic disease in zucchini plants in Indonesia, especially on the island of Bali, which is the center of zucchini cultivation by observation of the symptoms, proving Koch's postulates and using Indirect-ELISA serological tests.

\section{Materials and Methods}

\subsection{Observation of percentage of mosaic disease}

The study was conducted in the zucchini plantations of Baturiti District, Tabanan Regency and Sukasada District, Buleleng Regency in Bali Province. Observations were made on the plant population and the number of mosaic symptom plants were recorded. Zucchini plants that are sampled are those that show symptoms of contracting the virus with symptoms of a combination of mosaics, necrosis, vein clearing and malformations. The incidence of mosaic diseases for each zucchini plantation location is determined based on the percentage of disease events. The equality (1) used is:

$$
\mathrm{n} / \mathrm{N} \times 100 \%
$$

Where in: $\mathrm{n}=$ number of symptomatic plants, and $\mathrm{N}=$ number of observed plants

\subsection{Detection of viruses on Zucchini}

The presence of viruses in the zucchini plants was also observed through fulfill the Koch's postulates and serological tests with indirect-ELISA. Koch's postulate is a procedure to determine the cause of a plant disease caused by biotic agent, which consists of pathogen isolation, inoculation on similar healthy plants, re-isolation, and re-inoculation. ZYMV virus isolation to obtain infected leaf fluid was carried out by grinding 0.1 grams of infected leaves in phosphate buffer containing $1 \%$-mercaptoethanol $(0.01 \mathrm{M}, \mathrm{pH} 7.0)$ with a ratio of $1: 10(\mathrm{w} / \mathrm{v})$. ZYMV inoculation was done mechanically by applying infected leaf fluid to healthy leaves after being sprinkled with 600 mesh carborundum. The inoculated leaves were then rinsed with water to clean the remaining infected leaf fluid. Plants showing symptoms of ZYMV were then identified for the presence of the virus through I-ELISA using ZYMV, CMV, and PRSV specific antiserums. The indirect-ELISA method is carried out in accordance with DSMZ (Deutsche Sammlung von. Mikroorganismen und Zellkulturen GmbH) -Germany uses several antiserums namely, Zucchini yellow mosaic virus (ZYMV, DSMZ, Germany), Cucumber mosaic virus (CMV, Agdia Inc., USA) and Papaya spot ring virus (PRSV, Agdia Inc., USA). Negative controls were used from healthy zucchini plant extracts while positive controls were extracts of infected plants of different viruses (Agdia, USA). Virus accumulation is read quantitatively using ELISA Reader model 550 (Bio-Rad, USA) at a wavelength of $405 \mathrm{~nm}$. ELISA results are positive, if the absorbance value of the sample is twice higher than the absorbance value of the negative control (Matthews, 1992).

\section{Results and Discussion}

\subsection{The occurrence of mosaic disease in zucchini}

The occurrence of mosaic diseases in zucchini plantations appeared with very diverse symptoms of infection as malformation and distortion of leaves and fruit, blistering, vein cleansing, vein bending, and shoestring syptoms with disease ranging from $87.17 \%$ to $92.72 \%$ (Tables 1 and Figure 2). Koch's postulates were conducted by mechanical transmission using leaf extract resulted mosaic symptoms obtained $100 \%$ success rate. 
Identıfication of Vırus Causes of Mosaic Diseases in Zucchını Plants in the Balı Island of Indonesia

Where, the inoculated healthy zucchini plants inoculated with mosaic symptomatic plants exhibit the same symptoms as diseased plants found in the field. Symptoms of mosaic disease in the field vary greatly. Where, variations in symptoms appear as the response of plants to viral infections and are influenced by each susceptibility of the plant variety (genotype), viruses or insect vectors (Matthews, 1992).

The emergence of symptoms variations type on test plants can be caused the plant factors and virus strains (Walkey, 2012). According to Matthews (1992), the plant's symptoms variations infected with viruses are influenced by several factors, namely, plant age, cultivars, plant genotype and plant growth phases. Other factors also influence the symptoms of virus infections like environmental factors including soil fertility and climate as well.

Table 1. The occurrence of mosaic diseases on several zucchini plant centers in Bali

\begin{tabular}{lccc}
\hline $\begin{array}{c}\text { Zucchini planting } \\
\text { location }\end{array}$ & $\begin{array}{c}\text { Plant } \\
\text { population } \\
\text { x } 1.000\end{array}$ & $\begin{array}{c}\text { Zucchini attacked } \\
\text { mosaics } \\
\text { X 1.000 }\end{array}$ & $\begin{array}{c}\text { Disease occurrence } \\
(\%)\end{array}$ \\
\hline Pekarangan & 3.140 & 2.750 & 87.17 \\
Apit Yeh & 3.090 & 2.865 & 91.09 \\
Sandan & 2.518 & 2.195 & 92.00 \\
Titigalar & 1.886 & 1.718 & 87.36 \\
Batunya & 1.826 & 1.680 & 87.94 \\
Batusesa & 2.516 & 2.198 & 87.58 \\
KembangMerta & 4.395 & 3.865 & 92.72 \\
Asah Gobleg & 3.722 & 3.288 & 88.34 \\
Angseri & 3.740 & 3.392 & 90.70 \\
\hline Total & 26.833 & 23.951 & - \\
\hline Average & & - & 89.43 \\
\hline
\end{tabular}
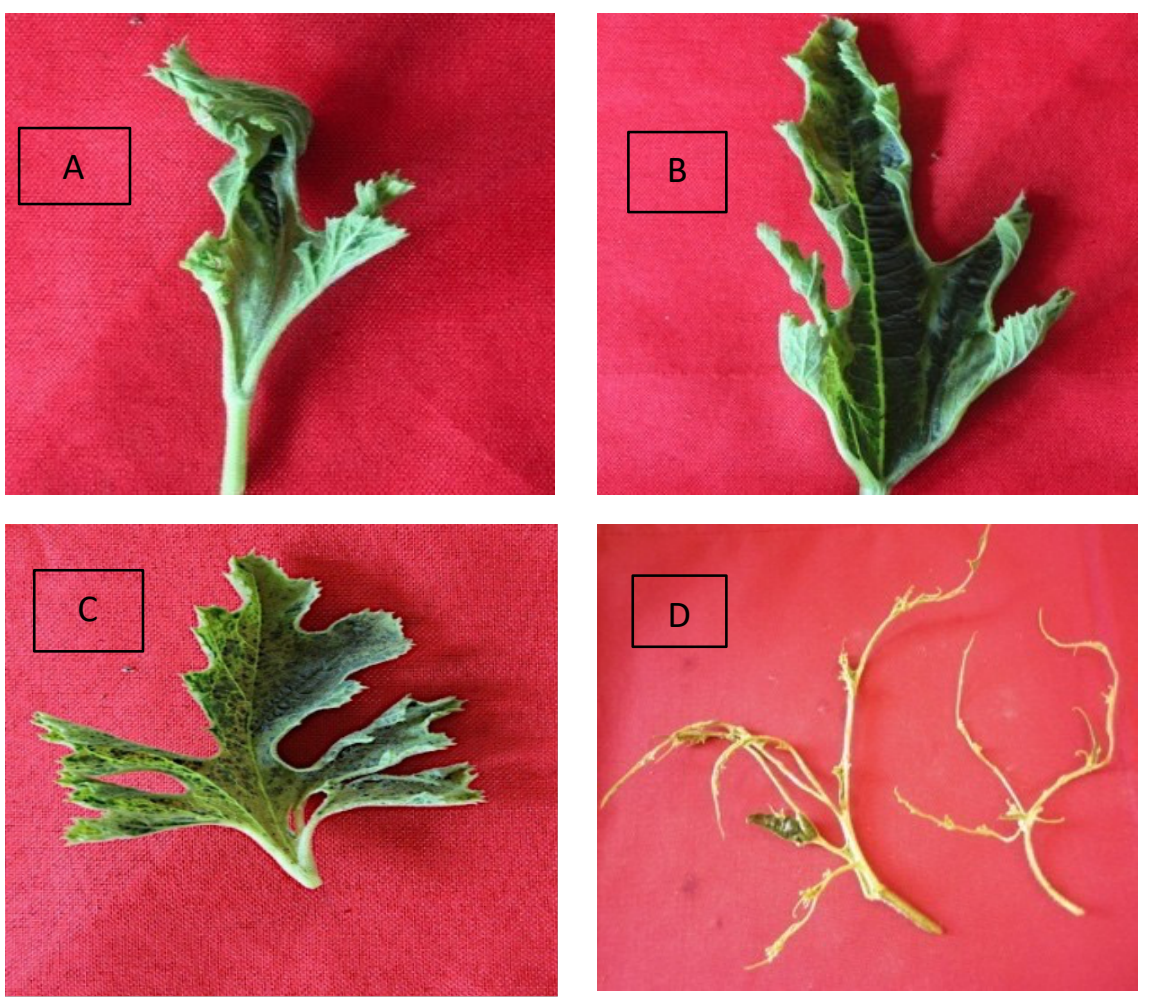

Figure 2. The variations on mosaic disease symptoms in zucchini (A) malformation, (B) leaf distortion, (C) blistering, (D) shoe-string 


\subsection{Results of serological tests}

For serological tests specific antisera were used detecting existance of ZYMV, PRSV and CMV. Regarding the samples with symptoms variety of 12 zucchini plantations, namely from Pekarangan, Apit Yeh, Sandan, Titigalar, Kembang Merta, Asah Gobleg, Angseri, Batunya, and Batusesa showed 75\% were positive infection to ZYMV: $8.33 \%$ were positive to CMV and $0 \%$ were infected by PRSV (Table 2).

Dwiwiyati (2014) stated that the symptoms of ZYMV infected plants vary greatly. As on cucumber plants in Sleman and Subang the symptoms appear on the leaves are not like yellow mosaic, and blistering. Symptoms of ZYMV on green kabocha squash in Bogor region showed vein opening, yellow-green mosaics, leaf malformations, chlorosis or dominantly bright green leaves blistering or dark green pox (Nurjannah, 2014).

In Hosseini et al. (2007), and Coutts et al. (2011b) study, ZYMV infected zucchini plants showed mosaic symptoms, blistering and leaf distortion. ZYMV infection mainly has occurred on squash, melon and watermelon. Symptoms of ZYMV on the plants are great yellow mosaics on leaves, leaf shape changes, changes on leaf size to be small and plants become stunted. On the pumpkin and squash, ZYMV infection causes discoloration and deformation cause changes on fruit shape (Provvidenti 1996; Tobias et al., 2003; Coutts, 2006).

Table 2. The existence of ZYMV, CMV, and PRSV by ELISA

\begin{tabular}{lccc}
\hline \multirow{2}{*}{ Sample source } & \multicolumn{4}{c}{ I-ELISA } & with specific antiserum \\
\cline { 2 - 5 } & ZYMV & CMV & PRsV \\
\hline Buffer & - & - & - \\
Positive control & + & + & + \\
Negative control & - & - & - \\
\hline Field sample & & & \\
\hline Pekarangan & + & - & - \\
Apit Yeh & + & - & - \\
Sandan 1 & + & - & - \\
Sandan 2 & + & - & - \\
Titigalar & + & - & - \\
Batuya & - & - & - \\
Batusesa & - & - & - \\
Kembang Merta & + & - & - \\
Gobleg 1 & - & + & - \\
Gobleg 2 & + & - & - \\
Angseri 1 & + & - & - \\
Angseri 2 & + & - & - \\
\hline Mechanical transmission & & & - \\
\hline Pekarangan & + & - & - \\
Apit Yeh & + & - & - \\
Kembang Merta & + & - & \\
\hline
\end{tabular}

Kece and Kamberoglu (2016), reported that biological, serological and molecular detection and identification of WMV-2 in watermelon growing fields in Adana, Mersin and Osmaniye provinces in the spring and summer months of 2012, showed that the presence of WMV infection in collected 182 samples were firstly investigated by ELISA and infection ratio was determined as $46.7 \%$. Selected WMV-2 isolates were used in mechanical inoculation and RT-PCR studies. In mechanical inoculation studies, squash (Cucurbita pepo L.), melon (Cucumis melo L.), cucumber (C. sativus L.) and watermelon (Citrillus lanatus (Thunb.) Matsum \& Nakai) produced mosaic, mottle, deformation and vein banding while C. quinoa Willd., C. amaranticolor Coste and Reynier and G. globosa L. showed chlorotic local lesions of leaves. WMV-2 did not induce any symptoms in tobacco species ( $N$. tabacum L., $N$. benthamiana L., $N$. glutinosa L. and $N$. rustica L.). In another study conducted by Önder and Korkmaz (2008), to determine prevalence of virus and viroid diseases using biological indexing for Exocortis and Satsuma dwarf, DAS-ELISA for Psorosis and DAS-ELISA and biological indexing for Citrus tristeza virus. DAS-ELISA test reveal that while 38 of 156 samples were infected with Citrus tristeza virus, none of the 10 samples tested 
was positive for Psorosis. Biological indexing showed that 1 of 20 samples tested was infected with Exocortis viroid, however no symptoms were observed from the Satsuma dwarf samples.

In Cucurbitaceae plantations in parts of Australia, the viruses causing severe production losses to reach $100 \%$ infection of pumpkin plants. Two potyviruses are responsible for mosaic disease, Papaya ringspot virus (PRSV$\mathrm{W}$ ), previously known as the watermelon mosaic virus (WMV-1), which has been known to cause problems for Cucurbitaceae since 1977. The second potyvirus is the Zucchini yellow mosaic virus (ZYMV). It has also been a cause of mosaic disease since 1989. Lestari and Nurhayati (2014) reported the presence of several viruses on Cucurbitaceae plants found in West Java included Cucumber mosaic virus (CMV), Squash mosaic virus (SqMV), and Zucchini yellow mosaic virus (ZYMV). ZYMV has been known in 22 countries on five continents (Zitter et al., 1996), including Indonesia. ZYMV is an important virus attacks plants belonging the Cucurbitaceae family worldwide. It has an important influence on Cucurbitaceae plants due to causing serious quantitative, qualitative and thereby serious economic lossest (Lin et al., 2000; Simmons et al., 2011).

Zucchini yellow mosaic potyvirus (ZYMV) was first identified in northern Italy. It likes other species of the family Potyviridae. ZYMV has been recorded in many countries since 1981. The efficient intercontinental spread of the virus can be explained by the international trading of infected seeds. Since coat protein $(\mathrm{CP})$ analysis has become a primary method for taxonomic assignment of potyviruses the aims were to characterize this genomic region of ZYMV originating from virus-infected cucurbitaceous seedlings. Virus infection in cucurbits is typically associated with mosaic symptoms on leaves and lumpy, distorted fruit. The range of symptoms produced by each virus can overlap and plants are commonly infected by more than one virus at once. The viruses are spread by many species of aphids moving through or within a crop. Control options include: destroying old cucurbit crops as soon as harvesting is completed destroying weeds and wild cucurbits, in and around plants. This situation will harbor viruses and/or aphids that separate new plants from mature plants as these will have a high viral infection rate to avoid overlapping cucurbit plants.

\section{Conclusions}

1) The occurrence of zucchini yellow mosaic virus in Bali show very diverse symptoms, namely malformation, distortion on leaves and fruit, blistering, vein clearing, vein-banding and shoestring like symptom.

2) The serology test resulted of the zucchini plantation with $75 \%$ positive infection by ZYMV, while $8.33 \%$ of the plants were infected by CMV and no zucchini plants were infected by PRSV

\section{Acknowledgment}

This research was supported by the Faculty of Agriculture, Mahasaraswati University Denpasar Bali Indonesia in the form of materials needed. For that we express our gratitude to the faculty and laboratory managers. 


\section{References}

Abd El-Aziz, M.H. (2020). The Importance of Potato virus Y Potyvirus. J Plant Sci Phytopathol. 2020; 4: 009-015.

Babadoost, M. (1999). Mosaic diseases of cucurbits. Erişim:[http://web. aces. uiuc. edu/vista/pdf_pubs/926. pdf]. Erişim Tarihi, 3, 2014. http://web.aces.uiuc.edu/vista/pdf_pubs/926.pdf

Barbosa, G.D.S., Lima, J.A.D.A., Queiróz, M.A.D., Dias, R.D.C.A., \& Lima, C.S. (2016). Identification and effects of mixed Infection of Potyvirus isolates with Cucumber mosaic virus in cucurbits. Rev. Caatinga, Mossoró, 29(4):1028-1035.

Coutts, B. (2006). Virus diseases of cucurbit crops. Virus diseases of cucurbit crops., (166).

Coutts, B. A., Kehoe, M. A., Jones, R. A. C. (2011a). Minimising losses caused by Zucchini yellow mosaic virus in vegetable cucurbit crops in tropical, sub-tropical and Mediterranean environments through cultural methods and host resistance. Virus research, 159(2) : 141-160. https://doi.org/10.1016/j.virusres.2011.04.015

Coutts, B. A., Kehoe, M. A., Webster, C. G., Wylie, S. J., Jones, R. A. C. (2011b). Zucchini yellow mosaic virus: biological properties, detection procedures and comparison of coat protein gene sequences. Archives of virology, 156(12):2119-2131. https://doi.org/10.1007/s00705-011-1102-0

Davis , R.F. \& Mizuki, M.K . (1986) Seed transmission of zucchini yellow mosaic virus in squash. Phytopathology $76: 1073$

Desbiez,C. \&, Lecoq, H. (1997). Zucchini yellow mosaic virus. 1997; Plant Pathol.46: 809-829.

Dwiwiyati, N. S. (2014). Begomovirus Characterization Causes of Curly Leaf Disease in Cucumbers (Cucumis sativus L.). (Thesis) Bogor: Bogor Agricultural University.

Fath-Allah M., Mostafa Ahmed A., \& Abou-Ela (2011). Sensitive detection of watermelon mosaic and zucchini yellow mosaic viruses from infected squash plants using serological methods and polymerase chain reaction. Egy J Experimental Biol (Bot.). 2011; 7(2): 179 - 185.

Fletcher, J.D., Wallace, A.R., \& Rogers, B.T. (2000). Potyviruses in New Zealand buttercup squash (Cucurbita maxima Duch.): yield and quality eff ects of ZYMV and WMV2 virus infections. New Zealand J Crop Horticult Sci. 2000; 28: 17-26.

Greber, R.S., McLean, G.D., \& Grice, M.S. (1987) Zucchini yellow mosaic virus in three states of Australia. Australas Plant Pathol 16:19-21

Greber, R.S., Persley, D.M., \& Herrington, M.E. (1988) Some characteristics of Australian isolates of zucchini yellow mosaic virus. Aust J Agric Res 39:1085-1094

Hosseini, S., Mosayebi, G., Kouhi, H. D. M., Okhovat, S. (2007). Characterization of the Zucchini yellow mosaic virus from squash in Tehran province. http://hehp.modares.ac.ir/article-23-8808-en.pdf

Jossey, S., Babadoost, M. (2008). Occurrence and distribution of pumpkin and squash viruses in Illinois. Plant disease, 92(1): 61-68. https://doi.org/10.1094/PDIS-92-1-0061

Kece, SM.A., \& Kamberoglu, M.A. 2016. Biological, serological and molecular detection of watermelon mosaic virus (WMN-2) in watermelon growing fields in eastern mediterranean region. Journal of Tekırdag Agricultural Faculty, 2016:13 (3)-156-164.

Lecoq, H. \& Pitrat, M. (1983) Field experiments on the integrated control of aphid-borne viruses in muskmel-ons. In: Plumb, R.T. and Thresh, J.M. (eds)Plant Virus Epidemiology. Blackwell, Oxford, pp. 169-176.

Lestari, S. M., Nurhayati, E. (2014). Efficiency of Squash Mosaic Virus Transmission in Cucurbitaceae. Jurnal Fitopatologi Indonesia, 10 (3) : 81. https://doi.org/10.14692/jfi.10.3.81

Lin, S. S., Hou, R. F., Yeh, S. D. (2000). Heteroduplex mobility and sequence analyses for assessment of variability of Zucchini yellow mosaic virus. Phytopathology, 90 (3) : 228-235. https://doi.org/10.1094/PHYTO.2000.90.3.228

Lisa, V., Boccardo G., D’Agostino G., Dellavalle G., \& D’Aquilio M. (1981). Characterization of a potyvirus that causes zucchini yellow mosaic. Phytopathology. 1981; 71: 667-672.

Önder,S., Korkmaz, S. 2008. Determination of virus and viroid diseases on satsuma owari mandarins by biological and serological methods in edremit gulf region. Journal of Tekırdag Agricultural Faculty, 2008:5 (2)-205-214.

Prieto, H., Bruna, A., Henrichsen P., \& Munoz, C.(2001). Isolation and molecular characterization of a Chilean isolate of Zucchini yellow mosaic virus. Plant Disease. 2001; 85: 644-648. PubMed: https://www.ncbi.nlm.nih.gov/pubmed/30823033

Matthews, R.E.F. (1992). Fundamentals of plant virology. Academic Press.

Nurjannah, T. (2014). Host Range of Zucchini yellow mosaic Isolate Kaboca Green virus (Cucurbita pepo L.). (thesis) Dep. Plant Protection Faculty of Agriculture IPB.

Prieto, H., Bruna, A., Hinrihsen P., Munoz, C.(2001). Isolation and molecular characterization of a Chilean isolate of Zucchini yellow mosaic virus. Plant Disease. 2001; 85: 644-648. PubMed: https:/www.ncbi.nlm.nih.gov/pubmed/30823033

Provvidenti, R. (1996). Diseases caused by viruses. Compendium of cucurbit diseases, 37-45.

Romay, G., Lecoq, H., \& Desbiez, C. (2014). Cucurbit crops and their viral diseases in Latin America and the Caribbean islands: A Review. J. Plant Pathol. 96(2):227-242. 
Pandawani N.P. \& Widnyana, I.K

Identıfication of Vırus Causes of Mosaic Diseases in Zucchını Plants in the Balı Island of Indonesia Schrijnwerkers, CCFM., Huijberts, N., \& Bos, L. (1991). Zucchini yellow mosaic virus: two outbreaks in the Netherlands and seed transmissability. NethJ P1 Path. 1991; 97: 187-191.

Simmons, H. E., Holmes, E. C., Gildow, F. E., Bothe-Goralczyk, M. A., \& Stephenson, A. G. (2011). Experimental verification of seed transmission of Zucchini yellow mosaic virus. Plant Disease, 95(6) : 751-754. https://doi.org/10.1094/PDIS-11-10-0843

Sydanmetsa, M., \& Mbanzibwa, D.R. (2016). Occurrence of Cucumber mosaic virus, Zucchini yellow mosaic virus and Watermelon mosaic virus in cultivated and wild cucurbits in the coastal areas of Tanzania. Afr. J. Agric. 11(40):4062-4069.

Tobias, I., \& Palkovics, L. (2003). Characterization of Hungarian isolates of zucchini yellow mosaic virus (ZYMV, potyvirus) transmitted by seeds of Cucurbita pepo var Styriaca. Pest Management Science: formerly Pesticide Science,59 (4) : $493-497$. https://doi.org/10.1002/ps.645

Walkey, D. G. (2012). Applied plant virology. Springer Science \& Business Media.

Zitter, T. A., Hopkins, D. L., \& Thomas, C. E. (1996). Compendium of cucurbit diseases (No. 635.6 632). American Phytopathological Society.

Zitter, T.A. \& Murphy, J.F. (2009). Cucumber mosaic. The Plant Health Instructor. DOI: 10.1094/PHI-I-2009-0518-01. 